\title{
Productive Response and Reproductive Performance of Dairy Cows Subjected to Different Feeding Systems
}

\section{Eloy Eduardo Salado1*, Martín Guillermo Maciel1', Gustavo Bretschneider², Alejandra Cuatrin1, Gerardo Antonio Gagliostro ${ }^{3}$}

\footnotetext{
${ }^{1}$ Area de Investigación en Producción Animal, Instituto Nacional de Tecnología Agropecuaria (INTA), Rafaela, Argentina

${ }^{2}$ Agencia de Extensión Rural Necochea, Instituto Nacional de Tecnología Agropecuaria (INTA), Necochea, Argentina

${ }^{3}$ Area de Investigación en Producción Animal, Instituto Nacional de Tecnología Agropecuaria (INTA), Balcarce, Argentina

Email: *salado.eloy@inta.gob.ar
}

How to cite this paper: Salado, E.E., Maciel, M.G., Bretschneider, G., Cuatrin, A. and Gagliostro, G.A. (2020) Productive Response and Reproductive Performance of Dairy Cows Subjected to Different Feeding Systems. Open Journal of Animal Sciences, $10,10-32$

https://doi.org/10.4236/ojas.2020.101002

Received: October 8, 2019

Accepted: November 29, 2019

Published: December 2, 2019

Copyright $\odot 2020$ by author(s) and Scientific Research Publishing Inc. This work is licensed under the Creative Commons Attribution International License (CC BY 4.0).

http://creativecommons.org/licenses/by/4.0/

(c) (i) Open Access

\begin{abstract}
Fifty Holstein cows (2.6 \pm 1.0 lactations) in early lactation (52.6 \pm 16.4 days in milk) calved in autumn and producing $34.3( \pm 4.4) \mathrm{kg}$ milk per cow.day ${ }^{-1}$ were randomly assigned for 27 weeks to one of two treatments (feeding systems) in 10 groups (pens) of 5 animals each (5 groups/treatment). The confined treatment was a total mixed ration (TMR_100) whereas the supplemented grazing system was defined by a partially mixed ration (PMR_75) with 75\% TMR and $25 \%$ oat pasture (Avena sativa L.) during the autum-winter (Period I) and alfalfa pasture (Medicago sativa $L$.) plus concentrate $(7.0 \mathrm{~kg}$ per cow $\cdot$ day $\left.^{-1}\right)(\mathrm{P}+\mathrm{C})$ during the next spring (Period II). Milk production was daily and individually recorded throughout the trial while the chemical composition of milk was measured on individual samples every 2 weeks. Live weight (LW) and body condition score (BCS) using a scale of 1 to 5 were recorded every 3 weeks after the morning milking. Simultaneously, blood samples were taken for determinations of glucose, urea, non-esterified fatty acids (NEFA), insulin, somatotrophin (GH) and somatomedin C (IGF-I). Total DM intake was measured using the difference method four times per repetition in the months of July, August, September and October. The experimental herd was inseminated at fixed time at the start of the service (May-July) and on the return with estrus detection. The diagnosis of pregnancy was made by transrectal ultrasonography at 30 and 60 days after the start of the service. The productive data were analyzed according to a model with repeated observations in time adjusted by covariate with 2 periods and using the animal as the experimental unit. Data of DM intake were analyzed using ANOVA for 2 treatments with 5 repetitions. Cows from the TMR_100
\end{abstract}


group produced more milk $\left(\mathrm{kg} \cdot \mathrm{cow}^{-1} \cdot \mathrm{day}^{-1}\right)$ during Period I (33.7 vs. 32.3$)$ and Period II $(28.8$ vs. 27.8$)(P<0.01)$. Yields were also higher $(P<0.05)$ in TMR_100 for milk fat $\left(\mathrm{kg} \cdot \mathrm{cow}^{-1} \cdot \mathrm{day}^{-1}\right)$ in Periods I (1.33 vs. 1.24$)$ and II ( 1.10 vs. 0.92$)$ and for milk protein ( 1.19 vs. 1.13 and 0.99 vs. 0.93$)$. The lower energy intake of grazing cows ( 45.0 vs. 43.1 and 40.9 vs. 38.9 Mcal per cow.day ${ }^{-1}$ for TMR_100 vs. PMR_75 and TMR_100 vs. P + C) coupled to the extra energy cost associated with grazing activity would explain the difference in milk production. Milk protein content $(\%)$ resulted higher $(P<0.05)$ in TMR_100 over the two experimental periods (3.53 vs. 3.47 and 3.42 vs. 3.31 ) while milk fat content (\%) was similar between TMR_100 vs. PMR_75 (3.90) but lower in P + C (3.30) compared to TMR_100 (3.87). The greatest LW gain $\left(\mathrm{kg} \cdot \mathrm{cow}^{-1} \cdot \mathrm{day}^{-1}\right)$ in the cows of the TMR_100 group in both periods (0.69 vs. 0.34 and 0.49 vs. -0.22 ) was consistent with the increase in the plasmatic levels of glucose and IGF-I and the reduction in the circulating levels of GH, but not with the lack of increases in plasma insulin concentration or decreases in circulating levels of NEFA, parameters that were not affected by treatments. Despite the positive effects of TMR_100 on parameters linked to energy balance, no significant differences were detected in any of the reproductive parameters evaluated and the final rate of pregnancy was 80.0 and 91.3\% for the confined and grazing system with supplementation respectively. Free milk liters over feeding costs were higher in the grazing system with supplementation compared to the confined system (18.5 vs. $15.5 \mathrm{l}$, respectively). The results indicate that the grazing system with supplementation can be economically competitive compared to the confined system of milk production.

\section{Keywords}

Milk Yield, Reproduction, Dairy Cow, Feeding Systems

\section{Introduction}

The need to release a certain amount of grazing land for agriculture generating sustainable mixed systems requires a certain degree of intensification of dairy farms [1]. For this reason, and although the local information about the confined systems is scarce, the confinement of dairy cows in Argentina is currently receiving particular attention. This context generates a growing demand for information on intensified feed systems that include partial or complete confinement strategies to replace grazing. Milk production systems tend to intensify using different alternatives. One of them consists of the confinement and total replacement of grazing by balanced rations defined as TMR. Among the main advantages attributed to this feeding system, it stands out to allow the expression of milk production potential in cows of high genetic merit. As a disadvantage, production costs are usually higher, mainly in feeding and labor, which together represent more than $50 \%$ of these components [2]. Another alternative to inten- 
sification is the combination of TMR and grazing, which is known as partially mixed rations (PMR) since the pasture does not constitute a physical part of the TMR. This semi-confined feeding system would allow obtaining partial advantages of both systems (pasture-based and confined). The use of pasture would reduce the amount of TMR in the total ration and consequently the feeding costs [3] [4] [5], improving health and animal welfare [6]. Although Argentine dairying is not excluded from the global trend of dairy farms intensification [7], there is a worldwide renewed interest in pasture-based systems [4] [8] [9] [10] [11]. According to [5] this interest is based on the lower expenses in feeds, equipment and infrastructure; improvement of animal health and reproduction (less culling); increasing pressure of regulatory organisms and the environmental care interest to reduce the accumulation of livestock waste and the improvement in life quality of the dairy farm workers (less stress, more free time, among other benefits).

Most studies that compared feeding systems have evaluated TMR vs. pasture without supplementation [12] [13] [14], TMR vs. pasture plus concentrate [4] [5] and TMR vs. pasture plus TMR [3] [15]. On the other hand, information on the expected response in feeding systems combining different proportions of TMR and pasture is scarce [16] [17] [18].

A comprehensive analysis of the available information indicates that milk and solids yields and total DM intake increase linearly with the level of inclusion of TMR in the diet in replacement of pasture, while no association was observed between conversion efficiency (CE) and the level of TMR intake [19]. This suggests that the difference in milk production in favor of diets with higher proportion of TMR would be associated to a higher DM intake. However, most of these studies have been carried out during short evaluation periods. Few comparative long term or full lactation studies have been conducted [4] [5] and none in Argentina. Confined cows consuming TMR produced $19 \%$ more milk (29.8 vs. 25.1 $\mathrm{kg} \cdot \mathrm{day}^{-1}$ ) than those on pasture-based systems but income over feeding costs resulted similar for the 3 feeding systems evaluated [5]. Researchers from North Carolina State University (USA) reported that a based-pasture milk production system proved competitive in terms of profitability [4] and reproductive performance [20] compared with a confined system. The group of grazing cows supplemented daily with a corn-based concentrate produced less milk (11\%) and had lower BCS and LW with fewer cases of clinical mastitis than the confined group consuming a nutritionally balanced TMR [20].

On the other hand, although numerous articles about factors that affect reproductive performance in dairy herds have been published, there are very few evaluating the effect of the production system [21]. Consequently, a long-term trial with the objective of evaluating the effects of two feeding systems, confined with TMR supply vs. grazing with supplementation applied in two seasons of a year, over the productive response and the reproductive performance of high genetic merit dairy cows was carried out. Additionally, the economic viability of the 2 systems was evaluated using simple indicators. 


\section{Materials and Methods}

\subsection{Experimental Site and Animals}

The trial was conducted using the research dairy herd of the National Institute of Agricultural Technology (INTA), located in Rafaela, province of Santa Fe, Argentina $\left(31^{\circ} 12^{\prime} \mathrm{S}, 61^{\circ} 30^{\prime} \mathrm{W}\right)$, from May to November 2011 and consisted of a 3 -week (covariate) pre-experimental period in which all cows received the control diet (100\% TMR) and of an experimental period of 27 weeks. Fifty Holstein dairy cows (milk yield $34.3 \pm 4.4 \mathrm{~kg} \cdot \mathrm{day}^{-1}$; days in milk $52.6 \pm 16.4$; parity $2.6 \pm$ 1.0; LW $586.6 \pm 59.4 \mathrm{~kg}$; mean $\pm \mathrm{SD}$ ) were used in this study. Animals were sorted on the basis of milk yield, parity and DIM and randomly assigned to one of 2 treatments (feeding systems) in 10 groups (pens) of 5 animals each (5 groups/treatment) in autumn-winter (Period I) and the subsequent spring (Period II). All cows were equipped with neck transponders that served to record daily milk production on an individual basis (ALPRO version 6.60/DeLaval, Tumba, Sweden). All procedures were consistent with the Guide for the Care and Use of Agricultural Animals in Agricultural Research and Teaching [22].

\subsection{Treatments}

In the confined system the cows received only the TMR without pasture (TMR_100) in both periods. In the grazing system with supplementation cows were fed $75 \%$ TMR plus $25 \%$ oats pasture (Avena sativa L.) during Period I (PMR_75) and alfalfa pasture (Medicago sativa L.) plus concentrate (7.0 $\mathrm{kg} \cdot \mathrm{cow}^{-1} \cdot$ day $\left.^{-1}\right)$ during Period II $(\mathbf{P}+\mathrm{C})$. This feeding system was defined based on the results obtained in previous trials conducted by the group [19] [23] [24]. The cows in TMR_100 had ad libitum access to the ration. The TMR was formulated based on [25] and was adjusted according to the requirements at the beginning of the second half of lactation. The autumn-winter TMR was composed (DM basis) by whole plant corn silage (32.6\%), pelletized concentrate (33.6\%), ground corn grain (5.4\%), soybean meal (7.5\%), cottonseed (5.7\%), soybeans $(7.2 \%)$ and alfalfa hay (7.6\%). Spring TMR was composed (DM basis) of whole plant corn silage (36.6\%), pelletized concentrate (27.8\%), ground corn grain $(5.2 \%)$, soybean meal $(7.5 \%)$, cottonseed $(4.5 \%)$, soybeans $(2.3 \%)$ and alfalfa hay (16.1\%). The ration was prepared using vertical mixing equipment (Mixer Juarez, Model 1400) and distributed in two daily offers at 6:00 $\mathrm{h}$ and 16:00 h: 50\%/50\% and 80\%/20\%, for TMR_100 and PMR_75, respectively. Cows were housed and fed in 2 dry-lots divided in turn into 5 pens of the same area each with ad libitum access to water. In PMR_75 treatment, the cows were taken to the grazing plot once they finished the pre-fixed TMR intake. The amounts of TMR offered in each treatment were weighed daily and refusals were recorded 3 times/week.

The potential DM intake (DMIp, $\mathrm{kg} \cdot \mathrm{cow}^{-1} \cdot \mathrm{day}^{-1}$ ) estimated during the last week of the pre-experimental period was used to define the pasture allowance $\left(\mathrm{PA}, \mathrm{kg} \mathrm{DM} \mathrm{cow}^{-1} \cdot \mathrm{day}^{-1}\right)$ of oat in a rotational grazing system. A PA equal to 2 
times the expected DM intake [26] was set for the PMR_75 treatment: $2 \times$ $(\mathrm{DMIp} \times 0.25)$, where DMIp $=26.0 \pm 1.0 \mathrm{~kg} \mathrm{DM} \mathrm{cow}^{-1} \cdot$ day $^{-1}$. The experimental concentrate was composed (wet basis) of corn grain (68\%), soybean meal (22\%), wheat bran (8\%) and vitamin-mineral premix with monensin and the alfalfa were used in a rotational grazing system with a PA of at least $30 \mathrm{~kg}$ DM $\mathrm{cow}^{-1} \cdot$ day $^{-1}[27]$.

\subsection{Measurements}

\subsubsection{Forage Biomass}

Weekly herbage biomass ( $\mathrm{kg} \mathrm{DM} \mathrm{ha}^{-1}$ ) was estimated by means of cuts at ground level with manual scissors in an area delimited by a metal frame of $0.125 \mathrm{~m}^{2}$, cutting a total area of $1 \mathrm{~m}^{2}$ in each sampling. The total sample, composed of $8 \mathrm{sub}$ samples of $0.125 \mathrm{~m}^{2}$, was dried in an oven at $65^{\circ} \mathrm{C}$ for 48 hours to determine its DM content. Based on this estimate, the area of the daily grazing strips was determined according to the defined PA.

\subsubsection{Chemical Composition of Feedstuffs}

Representative samples of the TMR, the ingredients that composed it, the experimental concentrate and the pastures (oats in autumn-winter and alfalfa in spring) were taken every 10 days. The latter were obtained manually in the grazing horizon simulating the selectivity of the cow (hand-plucking) [28]. All samples were dried in an oven with forced air circulation at $65^{\circ} \mathrm{C}$ to constant weight to determine the DM content and grinded in a Wiley mill ( $1 \mathrm{~mm}$ mesh). The content of neutral detergent fiber (NDF; [29]), acid detergent fiber (ADF; [30], procedure 973.18), ether extract (EE; [31], procedure 920.39), acid detergent lignin (ADL; [30], procedure 973.18), total nitrogen (Kjeldhal method; [31], procedure 976.05$)$, crude protein $(\mathrm{CP}$; total nitrogen $\times 6.25)$, ash $([30]$, procedure 942.05) and in vitro DM digestibility (IVDMD; [32]) was determined. The metabolizable energy content (ME) of the feedstuff was estimated with the following equation: $\mathrm{ME}\left(\mathrm{Mcal} \mathrm{kg} \mathrm{DM}{ }^{-1}\right)=4.4 \mathrm{Mcal}$ gross energy $(\mathrm{GE}) \mathrm{kg} \mathrm{DM}^{-1}$ * $0.82 *$ IVDMD and the net energy of lactation $\left(\mathrm{NE}_{1}\right)$ was calculated as $64 \%$ of $\mathrm{ME}$ [25]. TMR samples were also sieved and separated by size using the Penn State Particle Separator with two sieves (19 and $8 \mathrm{~mm}$ ) [33] obtaining three fractions: long particles $(>19 \mathrm{~mm})$, medium particles $(<19 \mathrm{~mm}$ and $>8 \mathrm{~mm})$ and short particles $(<8 \mathrm{~mm})$. The content of NDF $>8 \mathrm{~mm}$ physically effective (peNDF $>8$ ) was determined as the NDF content of the TMR multiplied by the proportion of particles retained in the 19 and $8 \mathrm{~mm}$ sieves of the Penn State Particle Separator [34].

\subsubsection{Milk Production and Composition}

Milk production was measured individually and daily by the milk measurement system DeLaval ALPRO (DeLaval International AB, Tumba, Sweden). Milk production from the last week of the pre-experimental period was used as a covariate. Milk composition was evaluated from individual samples collected every 2 weeks. Two milk subsamples were taken from each cow in consecutives milk- 
ings (morning and afternoon) using milk meters (DeLaval International $A B$, Tumba, Sweden), then a single individual sample (pool) weighted by the respective production was obtained. In each composite sample the content of fat, total protein, lactose, total solids (TS), non-fat solids (NFS) and urea was determined by infrared spectrophotometry (MilkoScan ${ }^{\mathrm{TM}}$ Minor; FOSS Electric, Hilleroed, Denmark) according to [35]. Milk casein content was calculated as 6.38 * (total $\mathrm{N}$ - non-casein N) after semi Micro-Kjeldhal digestion and colorimetric reading in Technicon continuous flow autoanalyzer according to [36]. Fat-corrected milk (4\% FCM) was calculated according to [37] and energy-corrected milk (ECM) as proposed by [38]. An additional sample of milk (covariate) was taken during the last week of the pre-experimental period.

\subsubsection{Live Weight and Body Condition Score}

The cows were weighed individually with an electronic scale every 3 weeks, after the morning milking and preventing access to water. The variation of LW between two successive weighings was calculated as the difference between the final weight minus the initial weight divided by the number of days elapsed. Along with the weighing, the BCS was determined by two independent observers using a 5 -point scale $(1=$ excessively thin and 5 = excessively fat $)$ with 0.25 increments [39] and the value analyzed was the average result of both evaluators.

\subsubsection{Dry Matter Intake}

Four determinations of total DM intake were performed per repetition covering a period of 6 consecutive days each, 2 in autumn-winter (July, August) and 2 in spring (September, October). The DM intake of TMR was determined by the difference between the quantities offered and rejected. For the measurement of pasture DM intake, each repetition was assigned to different grazing strips. On each paddock, pasture DM intake was estimated by difference between pre- and post-grazing pasture mass according to the method described by [40]. The determination of pasture DM intake by difference between pre- and post-grazing pasture mass has been compared with other techniques and validated by [41]. Herbage disappearance was measured within a brief gap of time $(24 \mathrm{~h})$. Therefore, pasture growth during assessment was not considered [42]. Within each pasture paddock, 10 pre- and 10 post-grazing pasture mass samples were taken, at fixed intervals, by clipping herbage contained into a $0.10 \mathrm{~m}^{2}$ circular frame at ground level with manual scissors. For the sampling, a transect line between diagonally opposite corners was extended. The transect line was a rope marked at $5.5 \mathrm{~m}$ intervals, all the way along its length. The diagonal transect was laid across the sampling area immediately prior to each pasture mass assessment (i.e., preand post-grazing). Each herbage mass assessment was randomly assigned to the left or right side of the transect line. In other words, if the pre-grazing pasture mass were assessed on the right side, the mass of the post-grazing pasture should be measured on the left side of the diagonal transect. Pre- and post-grazing measurements were made at the same time of the day $(11: 00 \mathrm{~h})$ on two consecu- 
tive days. Individual samples were put into paper bags and then, weighed and dried at $65^{\circ} \mathrm{C}$ for $48 \mathrm{~h}$ in a forced-air oven until constant weight to determine DM content.

\subsubsection{Plasma Concentration of Metabolites and Hormones}

Every 3 weeks, after the morning milking, blood samples were taken by puncture of the coccygeal vein. The blood was collected in tubes containing sodium heparin $(5 \mathrm{U} / \mathrm{ml})$. Plasma was obtained by centrifugation $\left(2000 \times \mathrm{g}\right.$ for $15 \mathrm{~min}$ at $4^{\circ}$ C) and stored at $-24^{\circ} \mathrm{C}$ until glucose (Enzymatic glycemia, Wiener Laboratory, Rosario, Argentina), urea (Uremia, Wiener Laboratory, Rosario, Argentina), non-esterified fatty acids (NEFA, Randox Laboratories Ltd., UK), insulin, growth hormone (GH) and somatomedin C or insulin-like growth factor (IGF-I) were analyzed as described in [43].

\subsubsection{Reproductive Performance}

The experimental herd was inseminated at a fixed time (fixed-time artificial insemination -TAI-) at the beginning of the reproductive season (May-July) and later, on return to estrus, with heat detection. Reproductive performance was assessed using the following indicators: TAI pregnancy (\%), pregnancy at 42 and 84 days post-start service (\%), final pregnancy (\%), abortions (\%) and calving-to-conception interval (CCI, days). The pregnancy diagnosis was carried out through transrectal ultrasonography (Aquila ultrasound, Pie Medical) with a 6 $\mathrm{MHz}$ linear transducer, 30 and 60 days after insemination.

\subsubsection{Economic Evaluation}

The economic evaluation of the studied feeding systems was carried out using the income over feeding cost, expressed in liters of milk.cow ${ }^{-1} \cdot$ day $^{-1}$ (free milk liters over feeding costs) as an indicator. This is a commonly used indicator [4], since it includes the primary source of income of a dairy farm (sale of milk) and the main component of the cost of production (feed). This evaluation was complemented by an analysis of sensitivity to variations in the price of milk ( $\$ /$ liter delivered) and of feeding costs [44].

\subsection{Statistical Analysis}

The quantitative variables were analyzed according to a completely randomized design with repeated observations in time adjusted by covariate $(\alpha=0.05)$, considering 2 periods: autumn-winter (Period I) and spring (Period II) and using the animal as the experimental unit. The following model was used:

$$
Y_{i j k}=\mu+T_{i}+W_{j}+A_{(i) k}+(T \times W)_{i j}+\operatorname{Cov}+E_{i j k},
$$

where:

$Y_{i j k}=$ dependent variable, $\mu=$ general mean, $T_{i}=$ treatment effect, $W_{j}=$ sampling week effect, $A_{(\hat{)})}=$ random effect of animal within treatment, $(T \times W)_{i j}=$ effect of treatment interaction $\times$ sampling week, $C o v=$ covariate and $E_{i j k}=$ residual error. Statistical analysis were performed using the MIXED procedure of 
the SAS statistical package [45].

Data referring to DM intake and conversion efficiency were analyzed by ANOVA for 2 treatments with 5 repetitions (pens). Qualitative variables were analyzed by difference of proportions using InfoStat [46].

\section{Results and Discussion}

\subsection{Chemical Composition of Feedstuffs}

The average values of the chemical composition of the pastures and the TMR used in the experiment are presented in Table 1. The chemical composition of the experimental concentrate was $90.2 \% \pm 1.1 \% \mathrm{DM}, 93.8 \% \pm 0.6 \% \mathrm{OM}, 18.2 \% \pm$ $1.2 \% \mathrm{CP}, 18.2 \% \pm 1.3 \% \mathrm{NDF}, 6.3 \% \pm 0.5 \% \mathrm{ADF}, 5.0 \% \pm 0.4 \% \mathrm{EE}$ and $86.0 \% \pm$ 3.6\% IVDMD. Herbage mass in the pregrazing strips of the oats and alfalfa pastures averaged $2366 \pm 312$ and $2074 \pm 178 \mathrm{~kg} \mathrm{DM} \mathrm{ha}^{-1}$, respectively.

The average DM content of the oats pasture (Table 1) was very close to the upper limit of the critical range (15\% - 18\%) that would affect consumption [47], while the average digestibility value was elevated and the average content of $\mathrm{CP}$ was within the range ( 150 - $\left.250 \mathrm{~g} \mathrm{CP} \mathrm{kg} \mathrm{DM}^{-1}\right)$ suggested by [48] in order to obtain high digestibility coefficients of the forage. In turn, the average NDF content of oats was well above the range of values $(34 \%-36 \%)$ that would allow maximizing the consumption of DM in dairy cows with a production level similar to that recorded in the present study [49]. These results would contribute to explaining the decrease in total DM intake due to the replacement of TMR by pasture in PMR_75 (Table 3). Taken together, the results indicate an apparent high quality of the oats pasture; being comparable to those reported by [50] for a similar pasture. However, the contents of DM and NDF resulted in potential DM intake limitations. On the other hand, alfalfa quality parameters were adequate

Table 1. Chemical composition of the feedstuffs used ${ }^{1}$.

\begin{tabular}{lcccc}
\hline \multicolumn{1}{c}{ Components } & Oats & $\begin{array}{c}\text { TMR } \\
\text { Period I }\end{array}$ & Alfalfa & $\begin{array}{c}\text { TMR } \\
\text { Period II }\end{array}$ \\
\hline DM (\%) & $18.3 \pm 1.5$ & $55.7 \pm 2.9$ & $22.1 \pm 1.5$ & $54.6 \pm 2.7$ \\
OM & $87.2 \pm 1.0$ & $93.1 \pm 0.5$ & $89.5 \pm 0.9$ & $92.8 \pm 0.5$ \\
IVDMD & $76.5 \pm 3.9$ & $74.0 \pm 3.9$ & $73.4 \pm 3.4$ & $73.0 \pm 3.5$ \\
CP & $21.0 \pm 1.8$ & $17.8 \pm 1.4$ & $24.7 \pm 1.8$ & $16.3 \pm 1.0$ \\
NDF & $44.3 \pm 3.7$ & $33.1 \pm 2.8$ & $38.0 \pm 3.2$ & $35.4 \pm 2.8$ \\
peNDF $>8$ & $\mathrm{nd}^{2}$ & $20.0 \pm 2.2$ & $\mathrm{nd}^{2}$ & $21.5 \pm 2.1$ \\
ADF & $21.1 \pm 1.6$ & $17.5 \pm 1.5$ & $21.0 \pm 1.7$ & $18.8 \pm 1.3$ \\
EE & $4.6 \pm 0.4$ & $5.5 \pm 0.4$ & $3.5 \pm 0.3$ & $4.9 \pm 0.4$ \\
\hline
\end{tabular}

${ }^{1}$ Values expressed through the average \pm the standard deviation. ${ }^{2}$ n.d. $=$ not determined. $\mathrm{DM}=$ dry matter; $\mathrm{OM}=$ organic matter; IVDMD = in vitro $\mathrm{DM}$ digestibility; $\mathrm{CP}=$ crude protein; $\mathrm{NDF}=$ neutral detergent fiber; $\mathrm{ADF}=$ acid detergent fiber; $\mathrm{EE}=$ ether extract; $\mathrm{peNDF}_{>8}=\mathrm{NDF}>8 \mathrm{~mm}$ physically effective, measured as the NDF content of the TMR multiplied by the percentage of particles retained in the 19 and $8 \mathrm{~mm}$ sieves of the Penn State Particle Separator [34]. 
in order to allow high DM intake and very close to the average values reported for pastures of this specie in a state of optimum use in spring by the forage quality assessment laboratory of the EEA Rafaela of INTA [51].

The quality parameters of the TMR used (Table 1) were within the ranges of values reported in other studies [3] [12] [15] [16] [18]. The contents of $\mathrm{peNDF}_{>8}$ average of the TMR (Table 1) were above the minimum required value (18.5\%) to prevent the development of subacute ruminal acidosis [52].

\subsection{Milk Production and Composition}

Most of the parameters of milk production and composition resulted significantly higher in TMR_100 for the two periods (Table 2), except contents of milk fat, TS, SNF and urea during Period I that remained unchanged $(P>0.05)$.

The cows of the TMR_100 group produced $4.3 \%$ and $3.6 \%$ more milk compared with those of the PMR_75 and P + C groups, during Periods I and II, respectively. Previous studies showed similar results [3] [4] [15].

In a 6-week study, researchers from Virginia State University (USA) reported that milk production $\left(29.1 \mathrm{~kg} \cdot\right.$ day $\left.^{-1}\right)$ of confined cows consuming TMR was significantly higher compared with cows consuming a.m. pasture (24\%) and p.m. TMR

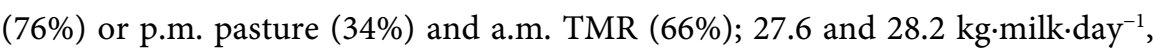

Table 2. Milk production and composition in dairy cows under two different feeding systems during the two experimental periods ${ }^{1}$.

\begin{tabular}{|c|c|c|c|c|c|c|c|c|}
\hline \multirow{3}{*}{ Variable } & \multirow{2}{*}{\multicolumn{2}{|c|}{$\begin{array}{c}\text { Period } \mathrm{I}^{2} \\
\text { Treatments }^{3}\end{array}$}} & \multirow{3}{*}{ SEM } & \multirow{3}{*}{$P<4$} & Period & & \multirow{3}{*}{ SEM } & \multirow{3}{*}{$\boldsymbol{P}<{ }^{4}$} \\
\hline & & & & & \multicolumn{2}{|c|}{ Treatments $^{3}$} & & \\
\hline & TMR_100 & PMR_75 & & & TMR_100 & $P+C$ & & \\
\hline Milk, kg.d $\mathrm{d}^{-1}$ & 33.7 & 32.3 & 0.16 & 0.01 & 28.8 & 27.8 & 0.21 & 0.01 \\
\hline $4 \% \mathrm{FCM}, \mathrm{kg} \cdot \mathrm{d}^{-1}$ & 33.4 & 31.6 & 0.32 & 0.01 & 28.3 & 25.1 & 0.28 & 0.01 \\
\hline $\mathrm{ECM}, \mathrm{kg} \cdot \mathrm{d}^{-1}$ & 33.3 & 31.8 & 0.30 & 0.01 & 27.7 & 25.3 & 0.30 & 0.01 \\
\hline Fat, $\mathrm{kg} \cdot \mathrm{d}^{-1}$ & 1.33 & 1.24 & 0.03 & 0.02 & 1.10 & 0.92 & 0.02 & 0.01 \\
\hline Fat, \% & 3.95 & 3.84 & 0.08 & 0.25 & 3.87 & 3.30 & 0.07 & 0.01 \\
\hline Protein, $\mathrm{kg} \cdot \mathrm{d}^{-1}$ & 1.19 & 1.13 & 0.02 & 0.02 & 0.99 & 0.93 & 0.02 & 0.01 \\
\hline Protein, \% & 3.53 & 3.47 & 0.02 & 0.02 & 3.42 & 3.31 & 0.02 & 0.01 \\
\hline Lactose, \% & 5.04 & 4.99 & 0.02 & 0.01 & 4.95 & 4.88 & 0.02 & 0.01 \\
\hline TS, $\%$ & 13.12 & 13.02 & 0.09 & 0.38 & 12.86 & 12.20 & 0.08 & 0.01 \\
\hline SNF, \% & 9.28 & 9.25 & 0.02 & 0.41 & 9.11 & 9.04 & 0.03 & 0.14 \\
\hline Urea, \% & 0.045 & 0.047 & 0.001 & 0.09 & 0.036 & 0.054 & 0.001 & 0.01 \\
\hline Casein, \% & 2.65 & 2.62 & 0.01 & 0.05 & 2.60 & 2.58 & 0.01 & 0.08 \\
\hline SCC & 5.01 & 5.09 & 0.05 & 0.19 & 5.16 & 5.22 & 0.05 & 0.38 \\
\hline
\end{tabular}


respectively [3]. The effects of two feeding systems (confined with TMR vs. grazing with supplementation) on the productive response of Holstein and Jersey cows were evaluated by [4] in a 4-year study. Results showed that cows in the grazing group with supplementation produced $11 \%$ less milk/lactation than cows fed with TMR. Likewise, cows (109 \pm 39 days in lactation) consuming TMR ad libitum produced $19 \%$ and 33\% more milk compared with cows consuming PMR (70\% TMR and 30\% pasture) and PC (60\% pasture plus $40 \%$ concentrate), respectively [15]. This result would be explained by differences in energy intake and the higher maintenance energy requirements related to grazing activity. Using the equations developed by [25], these researchers estimated that the energy cost of grazing activity was equivalent to $64 \%$ and $88 \%$ of the difference in milk production between TMR vs. PMR and TMR vs. PC, respectively. In the present study, assuming a content of $0.64 \mathrm{Mcal} \mathrm{NE} / \mathrm{kg}$ of milk it can be estimated [25] that the increase in energy requirements for maintenance would potentially represent 0.43 and $0.87 \mathrm{~kg}$ of milk for cows in PMR_75 and P + C, respectively. The observed decrease in energy intake (Table 3) plus the additional energy cost associated with grazing activity could explain the difference between treatments in milk production (Table 2) in accordance whit [12] who reported that in cows of high genetic merit $61 \%$ of the difference in milk production between a purely

Table 3. $\mathrm{DM}$ and $\mathrm{NE}_{1}$ intake and conversion efficiency (CE) in dairy cows under two different feeding systems during two periods ${ }^{1}$.

\begin{tabular}{|c|c|c|c|c|c|c|c|c|}
\hline \multirow{3}{*}{ Variable } & \multirow{2}{*}{\multicolumn{2}{|c|}{$\begin{array}{c}\text { Period } \mathrm{I}^{2} \\
\text { Treatments }^{3}\end{array}$}} & \multirow{3}{*}{ SEM } & \multirow{3}{*}{$P<4$} & \multirow{2}{*}{\multicolumn{2}{|c|}{$\begin{array}{c}\text { Period } \text { II }^{2} \\
\text { Treatments }^{3}\end{array}$}} & \multirow{3}{*}{ SEM } & \multirow{3}{*}{$P<4$} \\
\hline & & & & & & & & \\
\hline & TMR_100 & PMR_75 & & & TMR_100 & $P+C$ & & \\
\hline \multicolumn{9}{|l|}{$\mathrm{DM}, \mathrm{kg} \cdot \mathrm{day}^{-1}$} \\
\hline TMR & 26.3 & 19.2 & 0.18 & 0.01 & 24.2 & - & & \\
\hline Oats pasture & - & 5.8 & & & - & - & & \\
\hline Alfalfa pasture & - & - & & & - & 15.6 & & \\
\hline Total & 26.3 & 25.0 & 0.33 & 0.01 & 24.2 & 21.9 & 0.30 & 0.01 \\
\hline \multicolumn{9}{|l|}{$\mathrm{NE}^{5}$, Mcal day $^{-1}$} \\
\hline TMR & 45.0 & 32.8 & 0.30 & 0.01 & 40.9 & - & & \\
\hline Oats pasture & - & 10.3 & & & - & - & & \\
\hline Alfalfa pasture & - & - & & & - & 26.4 & & \\
\hline Total & 45.0 & 43.1 & 0.58 & 0.02 & 40.9 & 38.9 & 0.50 & 0.01 \\
\hline \multicolumn{9}{|l|}{$\mathrm{CE}$} \\
\hline kg Milk kg $\mathrm{DM}^{-1}$ & 1.28 & 1.29 & 0.03 & 0.86 & 1.19 & 1.27 & 0.03 & 0.06 \\
\hline $\mathrm{kg}$ ECM kg DM ${ }^{-1}$ & 1.27 & 1.28 & 0.02 & 0.81 & 1.17 & 1.17 & 0.02 & 0.97 \\
\hline
\end{tabular}


grazing system and one confined with TMR supply would be explained by the higher DM intake of the TMR, while grazing activity and the removal of excess urea would explain $24 \%$ and $12 \%$, respectively. These results are in line with [18] who reported that cows in early lactation consuming TMR ad libitum produced 10\% more milk compared with cows consuming TMR and pasture for 6 or 9 hours/day (73\% TMR: $27 \%$ pasture and 66\% TMR: $34 \%$ pasture, respectively) and concluded that this result would be explained by the differences observed in the total DM intake and in the net energy for maintenance requirements between the confined and grazing cows.

In Period II the treatment per week interaction was significant $(P<0.01)$ for milk production (Figure 1). During the first 7 weeks of the period, milk production was similar between treatments while from the $8^{\text {th }}$ week (week 22 of the experimental period) it was superior in TMR_100 with respect to $\mathrm{P}+\mathrm{C}$.

In the present study, a temporary decrease in milk production in the cows of the grazing group with supplementation would have been expected when changing from a diet with a high TMR content (PMR_75) to $\mathrm{P}+\mathrm{C}$ in spring. In this regard, a rapid reduction in milk production was observed by [53] when the cows moved from a diet with TMR to pasture plus concentrate. These researchers reported a difference of $3.6 \mathrm{~kg} \cdot \mathrm{day}^{-1}$ in milk production by autumn-calving Holstein cows grazing during the subsequent summer and supplemented with $6.2 \mathrm{~kg} \mathrm{DM} \mathrm{day}^{-1}$ of concentrate with respect to the projected milk production if the cows had remained confined consuming TMR. However, this difference would be somewhat overrated since the potential effect of heat stress for estimating projected milk production under confinement conditions was not taken into account and furthermore a short transition period (1 week) was used for the change of TMR to pasture plus concentrate. In the present study, the 3-week transition period (Figure 1) used for the change in the feeding of the grazing with supplementation group during the spring would help explain the absence of differences in milk production between TMR_100 and P + C during the first weeks of Period II.

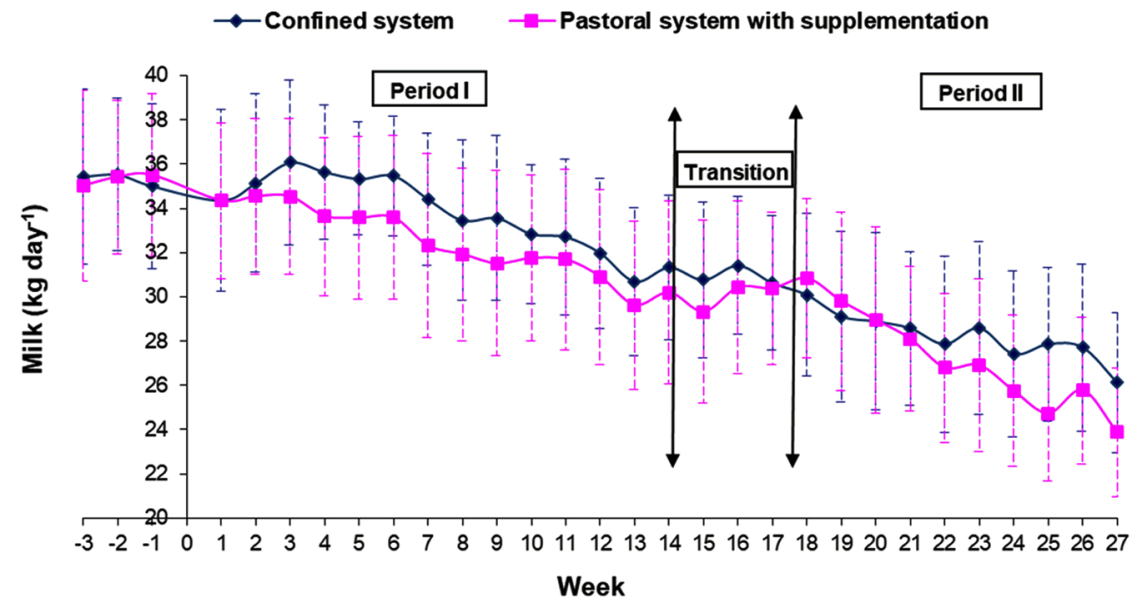

Figure 1. Evolution of milk production in dairy cows under two different feeding systems. 
Since milk fat concentration was not affected by treatments during Period I, the higher milk fat output observed in TMR_100 would be explained by the higher milk production of cows (Table 2) in accordance whit [15] who reported that milk fat content (3.30 vs. 3.35\%) did not differ, but yield of milk fat (1.24 vs. $\left.1.06 \mathrm{~kg} \cdot \mathrm{day}^{-1}\right)$ resulted higher in cows fed with TMR with respect to PMR (70\% TMR $+30 \%$ pasture), respectively. In Period II, both milk fat content and yield were significantly higher in TMR_100 compared with $\mathrm{P}+\mathrm{C}$ (Table 2). These results are in line with [15] who reported a higher fat content and yield in cows consuming TMR with respect to PC (60\% pasture $+40 \%$ concentrate) and attributed the lower concentration of milk fat in PC treatment to the consumption of highly digestible fiber from the pasture in combination with the supply of concentrate separated from the forage twice a day during each milking shift. In the present experiment, the concentrate was mixed with the other components of the ration in TMR_100 minimizing the selectivity. On the other hand, the average content of $\mathrm{peNDF}_{>8}$ of the TMR $(21.5 \pm 2.1)$ was above the minimum value suggested by [52] to prevent the development of subacute ruminal acidosis, which contribute to explain the results obtained.

Milk protein concentration and yield were significantly higher in TMR_100 over the 2 periods (Table 2) and would be explained by the higher energy intake (Table 3). These results were consistent with [15] who reported that cows fed TMR produced the highest amount of milk protein (1.13 vs. 0.93 vs. 0.79 $\left.\mathrm{kg} \cdot \mathrm{day}^{-1}\right)$ compared with PMR (70\% TMR $+30 \%$ pasture) and the PC treatment (60\% pasture $+40 \%$ concentrate), respectively; which was associated with a higher $\mathrm{NE}_{1}$ intake (43.7, 40.2 and 35.3 Mcal day ${ }^{-1}$, for TMR, PMR and PC, respectively).

Milk lactose content resulted higher in TMR_100 for the two periods (Table 2), suggesting a greater availability of glucose at the mammary gland level, a result compatible with the higher milk production obtained in this treatment. In turn, milk casein content was higher, while the milk urea level resulted lower in TMR_100 (Table 2) suggesting a better energy-protein balance at the ruminal level.

The SCC, considered an indicator of subclinical mastitis, was not affected by the treatments (Table 2) as reported by [12] [15] [54] when grazing vs. confined systems was compared. However, a dilution effect of SCC in high production cows without intramammary infection was reported by [55]. Since in TMR_100 the cows produced more milk (Table 2), actual differences in SCC could partly be masked by a dilution effect.

\subsection{DM and Energy Intake}

Total DM intake was significantly higher in TMR_100 compared with PMR_75 and also with P + C (Table 3) according to [15] [16] [18].

In Period I, total DM intake decreased when fresh forage replaced TMR leading to a TMR:pasture ratio of 77:23 as reported by [16] when combinations of 
TMR and pasture (annual ryegrass) were evaluated. The authors postulated that the reduction in total DM intake in groups of cows consuming PMR with respect to the group fed TMR ad libitum could be explained by restrictions on grazing time and alterations in daily grazing patterns imposed by the schedules of confinement of cows affecting pasture DM intake.

The effects of different grazing schedules and access times to the parcels were tested by [18] comparing one or two grazing sessions when they provided a PMR composed of 50\% pasture and 50\% TMR. The cows of the group with the longest access time to the pasture ( $6 \mathrm{~h}$ after the a.m. milking and $3 \mathrm{~h}$ after the p.m. milking) grazed 50 more minutes compared with the group with restricted access ( $6 \mathrm{~h}$ after the a.m. milking) achieving a greater pasture DM intake.

In the present study, qualitative deficiencies in pasture quality (DM deficit, NDF excess) added to putative factors linked to animal behavior could have affected pasture DM intake and therefore total DM intake in PMR_75. In turn, the total DM intake in the $\mathrm{P}+\mathrm{C}$ group (Table 3 ) was similar to that reported by [15] in cows fed $60 \%$ pasture plus $40 \%$ concentrate $\left(21.6 \mathrm{~kg} \mathrm{DM} \mathrm{day}^{-1}\right)$ and was within the range of values $\left(20.9-22.5 \mathrm{~kg} \mathrm{DM} \mathrm{day}^{-1}\right)$ obtained in previous trials [23] [24].

Total $\mathrm{NE}_{1}$ intake was higher in TMR_100 compared with PMR_75 and P + C (Table 3) and would be explained by the higher total DM intake, since the estimated $\mathrm{NE}_{1}$ content was higher in PMR_75 $\left(1.72 \mathrm{Mcal} \mathrm{kg} \mathrm{DM}^{-1}\right)$ and $\mathrm{P}+\mathrm{C}(1.78$ Mcal kg DM-1) with respect to TMR_100 (1.70 $\left.\mathrm{Mcal} \mathrm{kg} \mathrm{DM}^{-1}\right)$.

Conversion efficiency expressed as $\mathrm{kg}$ Milk $\mathrm{kg} \mathrm{DM}^{-1}$ was similar between TMR_100 and PMR_75, but tended $(P<0.06)$ to be higher in $\mathrm{P}+\mathrm{C}$ compared with TMR_100. The loss of LW $(P<0.01)$ observed in the cows of the $\mathrm{P}+\mathrm{C}$ treatment (Table 4) would be indicative of endogenous mobilization of energy to sustain milk production and would contribute to explaining the greater $\mathrm{CE}$ observed in this treatment.

\subsection{Changes in Live Weight, Body Condition Score and Plasma Concentration of Metabolites and Hormones}

The TMR_100 treatment increased LW and BCS gains (Table 4) according to the highest estimated $\mathrm{NE}_{1}$ intake (Table 3) without changes on plasma NEFA levels. These results suggest that cows in the TMR_100 group did not channel all the additional energy to milk production deriving a part towards body reserves reconstitution. On the other hand, the loss of LW in the $\mathrm{P}+\mathrm{C}$ group $(-0.22 \mathrm{~kg}$ day $^{-1}$ ) suggests that part of milk produced was obtained at the expense of endogenous energy mobilization as suggested by [5] even in cows in mid lactation.

Studies comparing confined feeding systems with TMR supply vs. grazing (with and without supplementation) often reported a negative effect of pasture inclusion on energy balance of high-yield dairy cows associated with lower DM and energy intake leading to losses of LW and BCS [5] [12] [15] [20] [56]. Cows fed TMR ad libitum either maintain LW and BCS [12] or increase these parameters 
Table 4. Changes $(\Delta)$ in live weight (LW), body condition score (BCS) and plasma concentration of metabolites and hormones in dairy cows under two different feeding systems during two periods ${ }^{1}$.

\begin{tabular}{|c|c|c|c|c|c|c|c|c|}
\hline \multirow{3}{*}{ Variable } & \multirow{2}{*}{\multicolumn{2}{|c|}{$\begin{array}{c}\text { Period } \mathrm{I}^{2} \\
\text { Treatments }^{3}\end{array}$}} & \multirow{3}{*}{ SEM } & \multirow{3}{*}{$P<4$} & Period & & \multirow{3}{*}{ SEM } & \multirow{3}{*}{$P<^{4}$} \\
\hline & & & & & \multicolumn{2}{|c|}{ Treatments $^{3}$} & & \\
\hline & TMR_100 & PMR_75 & & & TMR_100 & $P+C$ & & \\
\hline LW, kg & 631.5 & 607.6 & 3.47 & 0.01 & 672.0 & 618.1 & 4.68 & 0.01 \\
\hline$\Delta \mathrm{LW},{\mathrm{kg} \cdot \mathrm{day}^{-1}}^{-1}$ & 0.69 & 0.34 & 0.09 & 0.01 & 0.49 & -0.22 & 0.06 & 0.01 \\
\hline BCS & 2.77 & 2.67 & 0.04 & 0.03 & 3.25 & 2.97 & 0.06 & 0.01 \\
\hline$\triangle \mathrm{BCS}$ & 0.08 & 0.02 & 0.01 & 0.11 & 0.12 & 0.03 & 0.01 & 0.01 \\
\hline Glucose, $\mathrm{mmol} \cdot \mathrm{l}^{-1}$ & 3.73 & 3.61 & 0.03 & 0.02 & 3.65 & 3.36 & 0.03 & 0.01 \\
\hline Urea, mmol. $\mathrm{l}^{-1}$ & 7.51 & 7.38 & 0.11 & 0.40 & 6.59 & 8.72 & 0.13 & 0.01 \\
\hline NEFA, $\mu E q \cdot 1^{-1}$ & 159.1 & 168.8 & 7.3 & 0.34 & 125.5 & 140.1 & 7.7 & 0.20 \\
\hline $\mathrm{GH}, \mathrm{ng} \cdot \mathrm{ml}^{-1}$ & 2.82 & 3.52 & 0.23 & 0.02 & 2.85 & 3.26 & 0.17 & 0.09 \\
\hline Insulin, $\mathrm{ng} \cdot \mathrm{ml}^{-1}$ & 0.54 & 0.55 & 0.03 & 0.79 & 0.50 & 0.48 & 0.03 & 0.56 \\
\hline IGF-I, ng.ml ${ }^{-1}$ & 171.8 & 155.6 & 10.8 & 0.30 & 133.2 & 119.6 & 5.6 & 0.09 \\
\hline GH/Insulin & 6.75 & 7.22 & 0.75 & 0.66 & 6.83 & 7.70 & 0.59 & 0.30 \\
\hline
\end{tabular}

${ }^{1}$ Values are expressed as least squared means (LSMeans) and standard error of LSMeans (SEM). ${ }^{2}$ Period I = autumn-winter; Period II = spring. ${ }^{3}$ TMR_100 = totally mixed ration; PMR_75 = partially mixed ration; P + $\mathrm{C}=$ pasture plus concentrate. ${ }^{4}$ Treatment effect. $\mathrm{GH}=$ somatotrophin; NEFA = non-esterified fatty acids; IGF-I = somatomedin C.

[15] [56] while high yielding dairy cows fed only pasture mobilize body reserves with significant losses of body condition [12].

Plasma urea level (Table 4) was higher in P + C compared with TMR_100 according to the higher values of milk urea observed (Table 2) as reported by [15] in cows fed $60 \%$ pasture plus $40 \%$ concentrate compared with the TMR treatment. Plasma urea is a sensitive indicator of raw protein intake and its synchronism with the release of energy in the rumen, since its concentrations depends on the production and absorption of ruminal ammonium [57]. In this study, total CP intake was significantly higher $(P<0.01)$ in $\mathrm{P}+\mathrm{C}$ compared with TMR_100 (5.0 vs. $\left.3.9 \mathrm{~kg} \cdot \mathrm{day}^{-1}\right)$ keeping with the higher plasmatic concentration of urea in the $\mathrm{P}+\mathrm{C}$ group.

Plasma NEFA, glucose and regulatory hormones concentrations (insulin, GH and IGF-I) are dynamic or short-term indicators of energy balance [58]. The negative energy balance generates a decrease in the concentration of glucose, insulin and IGF-I and an increase in the plasma NEFA and GH levels [59]. In the present trial, plasma glucose was significantly higher in TMR_100 without changes in plasma insulin levels keeping with the highest energy intake (Table 3 ) and with the highest milk lactose content observed (Table 2).

Plasma IGF-I tended $(P=0.09)$ to decrease and $\mathrm{GH}$ to increase in $\mathrm{P}+\mathrm{C}$ respect to TMR_100 according to the lower energy intake of cows (Table 3). These results are in line with [60] who reported that mid lactation cows subjected to 
dietary restriction doubled the plasma concentration of $\mathrm{GH}$ and reduced circulating levels of IGF-I by approximately $50 \%$. The decrease in the number of GH receptors in liver tissue during periods of negative energy balance [61] would help explain the increase in the plasma concentration of GH and the reduction in liver production of IGF-I observed.

\subsection{Reproductive Performance}

Despite the positive effects of TMR_100 on parameters related to energy balance, the reproductive indicators evaluated were similar between treatments (Table 5).

These results were consistent with previously reported in [20] and [62]. The effects of two feeding systems (grazing with supplementation vs. confined with TMR) on the productive response and reproductive performance were evaluated by [20] in a 4-year study involving 282 Holstein and 222 Jersey cows. The cows group in grazing conditions showed a lower BCS and LW than confined group but reproductive performance did not differ showing average pregnancy percentages ( 75 days of service) of $64.2 \%$ and $71.7 \%$ for the confined and grazing groups, respectively. In turn, the effects of two feeding strategies (based-pasture diet vs. PMR composed of $79 \%$ TMR and $21 \%$ pasture) on the energy balance, metabolic changes and reproductive performance of Holstein cows during the first 9 weeks of lactation were studied by [62]. Results showed that despite the improvement in energy balance and reduction in the mobilization of body stores in cows fed with PMR, reproductive performance was not affected with pregnancy rates (84 days of service) of $72.1 \%$ and $77.1 \%$ for the PMR and the based-pasture groups, respectively.

In addition, a study of 17 dairy herds including various housing and feeding systems (confined and grazing) also found no relationship between the conception rate and the production system [63]. In line with these results, a semi-quantitative risk assessment carried out by the European Panel for Animal Health and Animal Welfare concluded that the risk of reproductive or metabolic disorders is independent of the production system [64].

\subsection{Economic Evaluation}

In spite of the higher income $(+4.0 \%)$ of the confined system compared to the grazing system with supplementation, the free milk liters over feeding costs were lower $(-16.2 \%)$, due to the higher costs $(+36.9 \%)$ of feeding (Table 6$)$.

These results agree with those reported in the literature indicating that the economic return of pasture-based systems was greater [3] [4] [56] or similar [5] to the traditional confined systems based on TMR. According to [65] intensive grazing systems would be more profitable than confined systems based on TMR, provided that the milk production of the former is up to $6 \%$ lower than that of confined herds. In the present study, the difference in milk production in favor of the confined system was within the range reported by these authors: $4.3 \%$ (31.5 vs. $30.2 \mathrm{~kg} \cdot$ day $\left.^{-1}\right)$. 
Table 5. Reproductive performance in dairy cows under two different feeding systems.

\begin{tabular}{lccc}
\hline \multicolumn{1}{c}{ Indicator } & Confined system & $\begin{array}{c}\text { Grazing system with } \\
\text { supplementation }\end{array}$ & $P<$ \\
\hline Assisted calvings, \% (n) & $12.0(3 / 25)$ & $21.7(5 / 23)$ & 0.45 \\
Pathological puerperium, \% (n) & $0.0(0 / 25)$ & $13.0(3 / 23)$ & 0.10 \\
$\mathrm{AI}^{1}$ 21 days, \% (n) & $68.0(17 / 25)$ & $73.9(17 / 23)$ & 0.76 \\
$\mathrm{TAI}^{2}, \%(\mathrm{n})$ & $32.0(8 / 25)$ & $26.1(6 / 23)$ & 0.76 \\
Pregnancy 42 days, \% (n) & $48.0(12 / 25)$ & $52.2(12 / 23)$ & 0.78 \\
Pregnancy 84 days, \% (n) & $64.0(16 / 25)$ & $65.2(15 / 23)$ & 1.00 \\
Final pregnancy, \% (n) & $80.0(20 / 25)$ & $91.3(21 / 23)$ & 0.42 \\
Abortions, \% (n) & $15.0(3 / 20)$ & $14.3(3 / 21)$ & 1.00 \\
CCI ${ }^{3}$, days $( \pm$ SD) & $132( \pm 86)$ & $144( \pm 95)$ & 0.65 \\
\hline
\end{tabular}

${ }^{1} \mathrm{AI} 21$ days $=$ inseminated cows the first 21 days of service. ${ }^{2} \mathrm{TAI}=$ fixed-time artificial insemination. ${ }^{3} \mathrm{CCI}=$ calving-to-conception interval.

Table 6. Economic evaluation of two different feeding systems during two periods.

\begin{tabular}{|c|c|c|c|c|c|c|}
\hline \multirow{3}{*}{ Variable } & \multirow{2}{*}{\multicolumn{2}{|c|}{$\frac{\text { Period I }^{1}}{\text { Treatments }^{2}}$}} & \multirow{2}{*}{\multicolumn{2}{|c|}{$\frac{\text { Period } \mathrm{II}^{1}}{\text { Treatments }^{2}}$}} & \multirow{2}{*}{\multicolumn{2}{|c|}{$\begin{array}{c}\text { Total period } \\
\text { Treatments }\end{array}$}} \\
\hline & & & & & & \\
\hline & TMR_100 & PMR_75 & TMR_100 & $\mathrm{P}+\mathrm{C}$ & CS & GSS \\
\hline Milk income $\left(\$ \cdot \text { cow }^{-1} \cdot \text { day }^{-1}\right)^{3}$ & 404.4 & 387.6 & 345.6 & 333.6 & 376.4 & 361.9 \\
\hline Ration costs $\left(\$ \cdot \operatorname{cow}^{-1} \cdot \text { day }^{-1}\right)^{4}$ & 173.6 & 148.8 & 143.3 & 102.9 & 159.2 & 127.0 \\
\hline Supply costs $\left(\$ \cdot \operatorname{cow}^{-1} \cdot \text { day }^{-1}\right)^{5}$ & 31.7 & 23.7 & 31.7 & 0.0 & 31.7 & 12.4 \\
\hline Income over feeding costs (\%) & 49.2 & 55.5 & 49.4 & 69.2 & 49.3 & 61.5 \\
\hline Free milk liters over feeding costs & 16.6 & 17.9 & 14.2 & 19.2 & 15.5 & 18.5 \\
\hline
\end{tabular}

${ }^{1}$ Period $\mathrm{I}=$ autumn-winter; Period II $=$ spring. ${ }^{2}$ TMR_100 = totally mixed ration; PMR_75 = partially mixed ration; $\mathrm{P}+\mathrm{C}=$ pasture pus concentrate; $\mathrm{CS}=$ confined system; GSS = grazing system with supplementation. ${ }^{3}$ Price of liter of milk: $\$ 12.0 /$ liter delivered. ${ }^{4}$ Prices as of April 2019. ${ }^{5}$ Includes maintenance costs of pens. US $\$$ value $=\$ 41.36$.

Only in one of the studies reviewed [44], the net income of the confined system for cows of high genetic merit $\left(45 \mathrm{~kg} \cdot \mathrm{milk}^{\mathrm{day}}{ }^{-1}\right)$ was superior despite presenting the highest production costs. However, the sensitivity analysis of the results showed that in scenarios of low price of milk and high cost of feed (situation not uncommon in Argentina), the grazing system with supplementation was more profitable than confined system. The sensitivity analysis carried out in the present study (Table 7) showed that the free milk liters over feeding costs were superior in the grazing system with supplementation for all the proposed scenarios, accentuating the differences with respect to the confined system in situations of low milk prices and high feeding costs.

Finally, it is worth clarifying that despite the high relative weight of feed in the costs, to compare the profitability of the systems, other production costs (labor, health, replacement, manure management) should also be considered, which as 
Table 7. Free milk liters over feeding costs based on changes in the price of milk and/or in the feeding costs of two different feeding systems during two periods.

\begin{tabular}{|c|c|c|c|c|c|c|}
\hline \multirow{3}{*}{ Variable } & \multirow{2}{*}{\multicolumn{2}{|c|}{$\begin{array}{c}\text { Period } \mathrm{I}^{1} \\
\text { Treatments }^{2}\end{array}$}} & \multirow{2}{*}{\multicolumn{2}{|c|}{$\begin{array}{c}{\text { Period } \mathrm{II}^{1}}^{\text {Treatments }^{2}}\end{array}$}} & \multirow{2}{*}{\multicolumn{2}{|c|}{$\begin{array}{l}\text { Total period } \\
\text { Treatments }^{2}\end{array}$}} \\
\hline & & & & & & \\
\hline & TMR_100 & PMR_75 & TMR_100 & $\mathrm{P}+\mathrm{C}$ & CS & GSS \\
\hline $\begin{array}{l}+20 \% \text { milk price, costs } \\
\text { without variation }\end{array}$ & 18.46 & 19.38 & 15.81 & 19.84 & 17.20 & 19.60 \\
\hline $\begin{array}{l}+10 \% \text { milk price, costs } \\
\text { without variation }\end{array}$ & 17.16 & 18.29 & 14.71 & 19.20 & 15.99 & 18.72 \\
\hline $\begin{array}{l}+10 \% \text { costs, milk price } \\
\text { without variation }\end{array}$ & 13.90 & 15.54 & 11.92 & 17.56 & 12.96 & 16.50 \\
\hline $\begin{array}{l}+20 \% \text { costs, milk price } \\
\text { without variation }\end{array}$ & 12.19 & 14.10 & 10.47 & 16.70 & 11.37 & 15.34 \\
\hline$-10 \%$ milk price, $+10 \%$ costs & 11.81 & 13.78 & 10.14 & 16.51 & 11.01 & 15.08 \\
\hline$-20 \%$ milk price, $+10 \%$ costs & 9.19 & 11.59 & 7.92 & 15.20 & 8.59 & 13.31 \\
\hline$-20 \%$ milk price,$+20 \%$ costs & 7.06 & 9.79 & 6.09 & 14.13 & 6.60 & 11.85 \\
\hline
\end{tabular}

${ }^{1}$ Period $\mathrm{I}=$ autumn-winter; Period II $=$ spring. ${ }^{2} \mathrm{TMR} \_100=$ totally mixed ration; PMR_75 = partially mixed ration; $\mathrm{P}+\mathrm{C}=$ pasture plus concentrate; $\mathrm{CS}=$ confined system; $\mathrm{GSS}=$ grazing system with supplementation. Price of liter of milk: $\$ 12.0 /$ liter delivered and feeding costs as of April 2019.

indicated by several reports worldwide are significantly lower in grazing systems, making them economically competitive with respect to confined systems; however, in the latter the need of land for forage production may be lower [4]. On the other hand, it should be borne in mind that for the total confinement of cows a high investment in facilities (dry lot or free-stall pen) is required, while for a partial confinement combined with grazing only a feed-pad would be required defined as a hard surface area designed solely for feeding.

\section{Conclusion}

Under the conditions of the present study, the improve in the productive parameters obtained in the confined feeding system was not important sufficiently to offset the higher feeding costs at the same value of the liter of milk produced calculated in the absence of bonuses per protein or casein content of milk. The putative economic advantages of the confined system based on a better reproductive response or metabolic health of the herd were not confirmed. Including pasture at $25 \%$ of total DM intake in the autumn-winter system seems to have been insufficient to induce an important shortage in DM and energy intakes capable of affecting productive and reproductive responses. Greater pasture participation could have accentuated the differences between systems in milk yield and BCS of high yielding dairy cows and in their reproductive response inducing negative residual effects in the subsequent spring with greater economic and physiological implications that deserve to be explored in future studies. The economic analysis confirmed some advantage for the grazing system with supplementation, a result that will be accentuated in situations of low milk prices 
and high feeding costs. In the context of a low autumn-winter pasture participation (25\% of total DM intake), the results indicate that the grazing system with supplementation is a more advantageous alternative compared to the confined system. An advisable strategy for autumn-calving cows would be to use a PMR during autumn-winter that will allow sustaining high milk yields and reproductive efficiency for later in spring, and with the herd in a more advanced stage of lactation, take advantage of lower grazing costs and use pastures with the strategic supplementation $(\mathrm{P}+\mathrm{C})$ implemented in this trial.

\section{Acknowledgements}

This work was supported by the National Institute of Agricultural Technology (INTA). This Institute is a decentralized state agency with operational and financial autarchy, under the Ministry of Agroindustry of the Argentine Republic. The authors thank Carlos Callaci for his assistance with economic evaluation, and Darío Arias for his assistance with the fieldwork.

\section{Conflicts of Interest}

The authors declare no conflicts of interest regarding the publication of this paper.

\section{References}

[1] Ramírez, L.M., Zuliani, S.B., Porstmann, J.C. and López, G.I. (2007) Historical Evolution of the Profitability of Agriculture and Dairy Farms in the South of Santa Fe Periods 1993/94 to 2004/05. Revista de Investigaciones de la Facultad de Ciencias Agrarias UNR, 7, 23-34.

[2] Short, S.D. (2004) Characteristics and Production Costs of U.S. Dairy Operations. USDA Statistical Bulletin No. 974-6. 20 p. ARMS of Milk Producers, USDA, ERS. https://doi.org/10.2139/ssrn.752005

[3] Soriano, F.D., Polan, C.E. and Miller, C.N. (2001) Supplementing Pasture to Lactating Holsteins Fed a Total Mixed Ration. Journal of Dairy Science, 84, 2460-2468. https://doi.org/10.3168/jds.S0022-0302(01)74696-6

[4] White, S.L., Benson, G.A., Washburn, S.P. and Green, J.T. (2002) Milk Production and Economic Measures in Confinement or Pasture Systems Using Seasonally Calved Holstein and Jersey Cows. Journal of Dairy Science, 85, 95-104. https://doi.org/10.3168/jds.S0022-0302(02)74057-5

[5] Fontaneli, R.S., Sollenberger, L.E., Littell, R.C. and Staples, C.R. (2005) Performance of Lactating Dairy Cows Managed on Pasture-Based or in Freestall Barn-Feeding Systems. Journal of Dairy Science, 88, 1264-1276. https://doi.org/10.3168/jds.S0022-0302(05)72793-4

[6] Arnott, G., Ferris, C.P. and O'Connell, N.E. (2017) Review: Welfare of Dairy Cows in Continuously Housed and Pasture-Based Production Systems. Animal, 11, 261-273. https://doi.org/10.1017/S1751731116001336

[7] Gastaldi, L., Litwin, G., Maekawa, M., Centeno, A., Engler, P., Cuatrin, A., Chimicz, J., Ferrer, J.L. and Suero, M. (2015) The Argentine Dairy Farm: An Integral View of the Milk Production Systems of the Pampean Region. Ediciones INTA. 
https://inta.gob.ar/sites/default/files/inta el tambo argentino mirada integral sis prod leche pamp abril 2015.pdf

[8] Fike, J.H., Staples, C.R., Sollenberger, L.E., Macoon, B. and Moore, J.E. (2003) Pasture Forages, Supplementation Rate, and Stocking Rate Effects on Dairy Cow Performance. Journal of Dairy Science, 86, 1268-1281. https://doi.org/10.3168/jds.S0022-0302(03)73711-4

[9] Dillon, P., Roche, J.R., Shalloo, L. and Horan, B. (2005) Optimising Financial Returns from Grazing in Temperate Pastures. In: Murphy, J.J., Ed., Utilisation of Grazed Grass in Temperate Animal Systems. Workshop of the 20 th International Grassland Congress, Wageningen Academic Publishers, Wageningen, 131-147.

[10] Macdonald, K.A., Penno, J.W., Lancaster, J.A.S. and Roche, J.R. (2008) Effect of Stocking Rate on Pasture Production, Milk Production, and Reproduction of Dairy Cows in Pasture-Based Systems. Journal of Dairy Science, 91, 2151-2163. https://doi.org/10.3168/jds.2007-0630

[11] Baudracco, J., Lopez-Villalobos, N., Holmes, C.W. and MacDonald, K.A. (2010) Effects of Stocking Rate, Supplementation, Genotype and Their Interactions on Grazing Dairy Systems: A Review. New Zealand Journal of Agricultural Research, 53, 109-133. https://doi.org/10.1080/00288231003777665

[12] Kolver, E.S. and Muller, L.D. (1998) Performance and Nutrient Intake of High Producing Holstein Cows Consuming Pasture or a Total Mixed Ration. Journal of Dairy Science, 81, 1403-1411. https://doi.org/10.3168/jds.S0022-0302(98)75704-2

[13] Kolver, E.S., Roche, J.R., De Veth, M.J., Thorne, P.L. and Napper, A.R. (2002) Total Mixed Rations versus Pasture Diets: Evidence for a Genotype $\mathrm{x}$ Diet Interaction in Dairy Cow Performance. Proceedings of the New Zealand Society of Animal Production, 62, 246-251.

[14] O’Neill, B.F., Deighton, M.H., O’Loughlin, B.M., Mulligan, F.J., Boland, T.M., O’Donovan, M. and Lewis, E. (2011) Effects of a Perennial Ryegrass Diet or Total Mixed Ration Diet Offered to Spring-Calving Holstein-Friesian Dairy Cows on Methane Emissions, Dry Matter Intake, and Milk Production. Journal of Dairy Science, 94, 1941-1951. https://doi.org/10.3168/jds.2010-3361

[15] Bargo, F., Muller, L.D., Delahoy, J.E. and Cassidy, T.W. (2002) Performance of High Producing Dairy Cows with Three Different Feeding Systems Combining Pasture and Total Mixed Rations. Journal of Dairy Science, 85, 2948-2963. https://doi.org/10.3168/jds.S0022-0302(02)74381-6

[16] Vibart, R.E., Fellner, V., Burns, J.C., Huntington, G.B. and Green, J.T. (2008) Performance of Lactating Dairy Cows Fed Varying Levels of Total Mixed Ration and Pasture. Journal of Dairy Research, 75, 471-480. https://doi.org/10.1017/S0022029908003361

[17] Morales-Almaráz, E., Soldado, A., González, A., Martínez-Fernández, A., Domínguez-Vara, I., de la Roza-Delgado, B. and Vicente, F. (2010) Improving the Fatty Acid Profile of Dairy Cow Milk by Combining Grazing with Feeding of Total Mixed Ration. Journal of Dairy Research, 77, 225-230. https://doi.org/10.1017/S002202991000004X

[18] Fajardo, M., Mattiauda, D.A., Motta, G., Genro, T.C., Meikle, A., Carriquiry, M. and Chilibroste, P. (2015) Use De Mixed Rations with Different Access Time to Pastureland on Productive Responses of Early Lactation Holstein Cows. Livestock Science, 181, 51-57. https://doi.org/10.1016/j.livsci.2015.09.023

[19] Salado, E.E., Bretschneider, G., Cuatrin, A., Descalzo, A.M. and Gagliostro, G.A. (2018) Productive Response of Dairy Cows Fed with Different Levels of Totally 
Mixed Ration and Pasture. Agricultural Sciences, 9, 824-851. https://doi.org/10.4236/as.2018.97058

[20] Washburn, S.P., White, S.L., Green, J.T. and Benson, G.A. (2002) Reproduction, Mastitis, and Body Condition of Seasonally Calved Holstein and Jersey Cows in Confinement or Pasture Systems. Journal of Dairy Science, 85, 105-111. https://doi.org/10.3168/jds.S0022-0302(02)74058-7

[21] Mee, J.F. (2012) Reproductive Issues Arising from Different Management Systems in the Dairy Industry. Reproduction in Domestic Animals, 47, 42-50. https://doi.org/10.1111/j.1439-0531.2012.02107.x

[22] ILAR (2010) Guide for the Care and Use of Laboratory Animals. 7th Edition, National Academy Press, Washington DC.

[23] Salado, E.E., Bretschneider, G., Cuatrin, A., Descalzo, A.M. and Gagliostro, G.A. (2017) Milk Yield and Composition and Pasture Ruminal Digestion in Grazing Dairy Cows Receiving Three Levels of Energy Concentrate Supplementation. Agricultural Sciences, 8, 1135-1156. https://doi.org/10.4236/as.2017.810083

[24] Salado, E.E., Bretschneider, G., Cuatrin, A. and Gagliostro, G.A. (2018) Effects of Supplementation with Increasing Levels of Energy Concentrate on the Productive Response and Ruminal Digestion of Dairy Cows Grazing Lucerne Pasture. Agricultural Sciences, 9, 1487-1505. https://doi.org/10.4236/as.2018.911104

[25] National Research Council (2001) Nutrient Requirements of Dairy Cattle. 7th Edition, National Academy of Sciences, Washington DC.

[26] Bargo, F., Muller, L.D., Kolver, E.S. and Delahoy, J.E. (2003) Invited Review: Production and Digestion of Supplemented Dairy Cows on Pasture. Journal of Dairy Science, 86, 1-42. https://doi.org/10.3168/jds.S0022-0302(03)73581-4

[27] Romero, L.A., Comeron, E.A., Bruno, O.A. and Díaz, M.C. (1995) Effect of the Level of Allocation of Alfalfa Pastures on the Response of Dairy Cows. 1. Intake and Ingestive Behavior. Memorias XIV Reunión Latinoamericana de Producción Animal y XIX Congreso Argentino de Producción de Producción Animal. Revista Argentina de Producción Animal, 15, 623-626.

[28] Meijs, J.A.C., Walters, R.J.K. and Keen, A. (1982) Sward Methods. In: Leaver, J.D., Ed., Herbage Intake Handbook, The British Grassland Society, Grassland Research Institute, Hurley, 11-37.

[29] Komarek, A.R. (1993) An Improved Filtering Technique for the Analysis of Neutral Detergent Fiber and Acid Detergent Fiber Utilizing the Filter Bag Technique. Ankom Tech. Corp., Fairport, Publication No. 101, 1-10.

[30] AOAC (Association of Official Analytical Chemists) (1990) Official Methods of Analysis. 15th Edition, Arlington.

[31] AOAC (Association of Official Analytical Chemists) (1998) Official Methods of Analysis. 16th Edition, Arlington.

[32] Tilley, J.M.A. and Terry, R.A. (1963) A Two-Stage Technique for in Vitro Digestion of Forage Crops. Journal of the British Grassland Society, 18, 104-111. https://doi.org/10.1111/j.1365-2494.1963.tb00335.x

[33] Lammers, B.P., Buckmaster, D.R. and Heinrichs, A.J. (1996) A Simple Method for the Analysis of Particle Sizes of Forage and Total Mixed Rations. Journal of Dairy Science, 79, 922-928. https://doi.org/10.3168/jds.S0022-0302(96)76442-1

[34] Zebeli, Q., Mansmann, D., Steingass, H. and Ametaj, B.N. (2010) Balancing Diets for Phyphosically Effective Fibre and Ruminally Degradable Starch: A Key to Lower the Risk of Sub-Acute Rumen Acidosis and Improve Productivity of Dairy Cattle. 
Livestock Science, 127, 1-10. https://doi.org/10.1016/j.livsci.2009.09.003

[35] ISO 9622 IDF 141 (2013) Milk and Liquid Milk Products-Guidelines for the Application of Mid-Infrared Spectrometry.

[36] Ovejero, F. (1987) Chemical and Biological Chemical Evaluation of Forages. Dirección de Desarrollo de Recursos Humanos. COMCAL.

[37] Gaines, W.L. and Davidson, F.A. (1923) Relation between Percentage of Fat Content and Yield of Milk. Univ. of Illinois Agri. Expt. Sta, Bull. 245.

[38] Tyrrell, H.F. and Reid, J.T. (1965) Prediction of the Energy Value of Cows Milk. Journal of Dairy Science, 48, 1215-1223. https://doi.org/10.3168/jds.S0022-0302(65)88430-2

[39] Wildman, E.E., Jones, G.M., Wagner, P.E., Boman, R.L., Troutt, H.F. and Lesch, T.N. (1982) A Dairy Cow Body Condition Scoring System and Its Relationship to Selected Production Characteristics. Journal of Dairy Science, 65, 495-501. https://doi.org/10.3168/jds.S0022-0302(82)82223-6

[40] Gallardo, M.R., Castillo, A.R., Bargo, F., Abdala, A.A., Maciel, M.G., Perez-Monti, H., Castro, H.C. and Castelli, M.E. (2005) Monensin for Lactating Dairy Cows Grazing Mixed-Alfalfa Pasture and Supplemented with Partial Mixed Ration. Journal of Dairy Science, 88, 644-652. https://doi.org/10.3168/jds.S0022-0302(05)72728-4

[41] Macoon, B., Sollenberger, L.E., Moore, J.E., Staples, C.R., Fike, J.H. and Portier, K.M. (2003) Comparison of Three Techniques for Estimating the Forage Intake of Lactating Dairy Cows on Pasture. Journal of Animal Science, 81, 2357-2366. https://doi.org/10.2527/2003.8192357x

[42] Mannetje, L. (1978) Measuring Quantity of Grassland Vegetation. In: Mannetje, L., Ed., Measurement of Grassland Vegetation and Animal Production, Commonwealth Bureau of Pastures and Field Crops, Commonwealth Agricultural Bureaux, Farnham Royal, Bucks, Bull. 52, 63-95.

[43] Salado, E.E., Gagliostro, G.A., Becu-Villalobos, D. and Lacau-Mengido, I. (2004) Partial Replacement of Corn Grain by Hydrogenated oil in Grazing Dairy Cows in Early Lactation. Journal of Dairy Science, 87, 1265-1278. https://doi.org/10.3168/jds.S0022-0302(04)73277-4

[44] Tozer, P.R., Bargo, F. and Muller, L.D. (2003) Economic Analyses of Feeding Systems Combining Pasture and Total Mixed Ration. Journal of Dairy Science, 86, 808-818. https://doi.org/10.3168/jds.S0022-0302(03)73663-7

[45] SAS Institute Inc. (2010) SAS/STAT ${ }^{\circ}$ User's Guide (2002-2010). SAS Institute, Cary.

[46] Di Rienzo, J.A., Casanoves, F., Balzarini, M.G., Gonzalez, L., Tablada, M. and Robledo, C.W. (2011) InfoStat Version 2011. Grupo InfoStat, FCA, Universidad Nacional de Córdoba, Argentina. http://www.infostat.com.ar

[47] Verité, R. and Journet, M. (1970) Influence of Moisture Content and Dehydration of Grass on Its Feed Value for Dairy Cows. Annales de zootechnie, INRA/EDP Sciences, 19, 255-268. https://hal.archives-ouvertes.fr/hal-00887007

[48] Minson, D.J. (1990) Forage in Ruminant Nutrition. Academic Press, Inc., Queensland. https://doi.org/10.1016/B978-0-12-498310-6.50019-5

[49] Mertens, D.R. (1994) Regulation of Forage Intake. In: Fahey Jr., E. and Madison, G.G., Eds., Forage Quality, Evaluation and Utilization, Am. Soc. Agron., Inc., Crop Sci. Soc. Am., Soil Sci. Soc. Am., Inc., Madison, 59-114.

[50] Quilaguy, G.A. (2015) Productive Response of Dairy Cows Fed with Different Levels of Totally Mixed Ration and Pasture. Programa de Posgrado en Ciencias 
Agrarias. Curso de Posgrado en Producción Animal-Ciclo Académico 2009-2011. Facultad de Ciencias Agrarias-Universidad Nacional de Mar del Plata. Estación Experimental Agropecuaria de Balcarce-INTA.

[51] Gaggiotti, M. (2008) Chemical Composition Table of Feed for Ruminant. Ediciones INTA. 67 p.

[52] Zebeli, Q., Aschenbach, J.R., Tafaj, M., Boguhn, J., Ametaj, B.N. and Drochner, W. (2012) Invited Review: Role of Physically Effective Fiber and Estimation of Dietary Fiber Adequacy in High-Producing Dairy Cattle. Journal of Dairy Science, 95, 1041-1056. https://doi.org/10.3168/jds.2011-4421

[53] Wu, Z., Kanneganti, V.R., Massingill, L.J., Wiltbank, M.C., Walgenbach, R.P. and Satter, L.D. (2001) Milk Production of Fall-Calving Dairy Cows during Summer Grazing of Grass or Grass-Clover Pasture. Journal of Dairy Science, 84, 1166-1173. https://doi.org/10.3168/jds.S0022-0302(01)74577-8

[54] AbuGhazaleh, A.A., Felton, D.O. and Ibrahim, S.A. (2007) Milk Conjugated Linoleic Acid Response to Fish Oil and Sunflower Oil Supplementation to Dairy Cows Managed under Two Feeding Systems. Journal of Dairy Science, 90, 4763-4769. https://doi.org/10.3168/jds.2007-0163

[55] Green, L.E., Schukken, Y.H. and Green, M.J. (2006) On Distinguishing Cause and Consequence: Do High Somatic Cell Counts Lead to Lower Milk Yield or Does High Milk Yield Lead to Lower Somatic Cell Count? Preventive Veterinary Medicine, 76, 74-89. https://doi.org/10.1016/j.prevetmed.2006.04.012

[56] Tucker, W.B., Rude, B.J. and Wittayakun, S. (2001) Case Study: Performance and Economics of Dairy Cows Fed a Corn Silage-Based Total Mixed Ration or Grazing Annual Ryegrass during Mid to Late Lactation. The Professional Animal Scientist, 17, 195-201. https://doi.org/10.15232/S1080-7446(15)31622-3

[57] Noro, M., Vargas, V., Pulido, R.G. and Wittwer, F. (2006) Effect of the Type of Concentrate on Blood Indicators of Energy and Protein Metabolism in Dairy Cows in Spring Grazing. Archivos de Medicina Veterinaria, 38, 227-232.

[58] Chilliard, Y., Bocquier, F. and Doreau, M. (1998) Digestive and Metabolic Adaptations of Ruminants to Undernutrition, and Consequences on Reproduction. Reproduction Nutrition Development, 38, 131-152. https://doi.org/10.1051/rnd:19980201

[59] Van Knegsel, A.T.M., Van der Brand, H., Graat, E.A.M., Dijkstra, J., Jorritsma, R., Decuypere, E., Tamminga, S. and Kemp, B. (2007) Dietary Energy Source in Dairy Cows in Early Lactation: Metabolites and Metabolic Hormones. Journal of Dairy Science, 90, 1477-1485. https://doi.org/10.3168/jds.S0022-0302(07)71633-8

[60] McGuire, M.A., Bauman, D.E., Dwyer, D.A. and Cohick, W.S. (1995) Nutritional Modulation of the Somatotropin/Insulin-Like Growth Factor System: Response to Feed Deprivation in Lactating Cows. The Journal of Nutrition, 125, 493-502.

[61] Breier, B.H., Gluckman, P.D. and Bass, J.J. (1988) The Somatotrophic Axis in Young Steers: Influence of Nutritional Status and Oestradiol-17b on Hepatic Highand Low-Affinity Somatotrophic Binding Sites. Journal of Endocrinology, 116, 169-177. https://doi.org/10.1677/joe.0.1160169

[62] Pedernera, M., Garcia, S.C., Horagadoga, A., Barchia, I. and Fulkerson, W.J. (2008) Energy Balance and Reproduction on Dairy Cows Fed to Achieve Low or High Milk Production on a Pasture-Based System. Journal of Dairy Science, 91, 3896-3907. https://doi.org/10.3168/jds.2008-1098

[63] Dransfield, M.B.G., Nebel, R.L., Pearson, R.E. and Warnick, L.D. (1998) Timing of Insemination for Dairy Cows Identified in Estrus by a Radiotelemetric Estrus De- 
tection System. Journal of Dairy Science, 81, 1874-1882.

https://doi.org/10.3168/jds.S0022-0302(98)75758-3

[64] EFSA (2009) Scientific Opinion on Welfare of Dairy Cows in Relation to Metabolic and Reproductive Problems Based on a Risk Assessment with Special Reference to the Impact of Housing, Feeding Management and Genetic Selection. EFSA Journal, 7, 1140. https://doi.org/10.2903/j.efsa.2009.1140

[65] Elbehri, A. and Ford, S.A. (1995) Economic Analysis of Major Dairy Forage Systems in Pennsylvania: The Role of Intensive Grazing. Journal of Production Agriculture, 4, 449-507. https://doi.org/10.2134/jpa1995.0501 